¿CHICANA POWER! 
CHICANA MATTERS SERIES, DEENA J. GONZÁLEZ

AND ANTONIA CASTAÑEDA, EDITORS

Chicana Matters Series focuses on one of the largest population groups in the United States today, documenting the lives, values, philosophies, and artistry of contemporary Chicanas. Books in this series may be richly diverse, reflecting the experiences of Chicanas themselves, and incorporating a broad spectrum of topics and fields of inquiry. Cumulatively, the books represent the leading knowledge and scholarship in a significant and growing field of research and, along with the literary works, art, and activism of Chicanas, underscore their significance in the history and culture of the United States. 


\section{ICHICANA POWER!}

Contested Histories of Feminism

in the Chicano Movement

MAYLEI BLACKWELL

UNIVERSITY OF TEXAS PRESS $\mathbf{v}$ Austin 
Copyright (C) 2011 by the University of Texas Press

All rights reserved

Printed in the United States of America

Sixth paperback printing, 2015

Requests for permission to reproduce material from this work should be sent to:

Permissions

University of Texas Press

P.O. Box 7819

Austin, TX 78713-7819

http://utpress.utexas.edu/index.php/rp-form

(a) The paper used in this book meets the minimum requirements of ANSI/NISO Z39.48-1992 (R1997) (Permanence of Paper).

Earlier versions of chapter 3 were published as "Bearing Bandoleras: Transfigurative Liberation and the Iconography of la Nueva Chicana," in Beyond the Frame: Women of Color and Visual Representations, eds. Neferti X. M. Tadiar and Angela Y. Davis (New York: Palgrave, 2005), 171-196, reprinted with permission of Palgrave Macmillan, and "Contested Histories: las Hijas de Cuauhtémoc, Chicana Feminisms and Print Culture in the Chicano Movement, 1968-1973," in Chicana Feminisms: A Critical Reader, eds. Gabriela Arredondo, Aída Hurtado, Norma Klahn, Olga Nájera-Ramírez, and Patricia Zavella (Durham, NC: Duke University Press, 2003), 59-89, reprinted with permission.

LIBRARY OF CONGRESS CATALOGING-IN-PUBLICATION DATA

Blackwell, Maylei, 1969-

iChicana power! : contested histories of feminism in the Chicano movement /

by Maylei Blackwell. - lst ed.

p. $\quad \mathrm{cm} .-$ (Chicana matters series)

Includes bibliographical references and index.

ISBN 978-0-292-72690-1 (pbk. : alk. paper)

1. Mexican American women. 2. Feminism-United States. 3. Women political activists-United States. I. Title.

E184.M5B55 2011

$305.48^{\prime} 86872073-\mathrm{dc} 22$

2011006831

doi: $10.7560 / 725881$ 